ARTICLE

\title{
Translation and solidarity in the century with no future: prefiguration vs. aspirational translation
}

Mona Baker (1) ${ }^{1 凶}$

\begin{abstract}
The future and how we envision and anticipate it has been the subject of scholarly attention for some time, especially from political theorists, scholars of human geography, and anthropologists. This article draws on some of this literature, but particularly the work of Franco 'Bifo' Berardi, the Italian Marxist theorist and activist, to explore the implications of two activist strategies that have recently received some attention from translation scholars: prefiguration and aspirational translation. It reflects on the different orientations to the future implied in these two strategies and suggests that their relative appeal is impacted by the rise of semiocapitalism in what Berardi refers to as 'the century with no future', and by varying experiences of activists located in different regions of the world. The work of translation and how translators orient themselves to the future, it is argued, can play an important role in arresting if not reversing the ongoing erosion of those possibilities still inscribed in the present despite semiocapitalism's growing control over every area of human life.
\end{abstract}

${ }^{1}$ Baker Centre for Translation \& Intercultural Studies, Shanghai International Studies University, Shanghai, China. ${ }^{凶}$ email: mona.baker@manchester.ac.uk 


\section{Introduction}

he starting point of this article is that all aspects of our experience of the world are mediated, including our experience of time and of space. In what follows, I focus specifically on time and the implications of this statement for activist strategies of translation in what Franco Berardi (2011) has dubbed 'the century with no future', referring to the 21st century, as opposed to activist strategies that have been advocated and had made sense in the 20th and early part of this century. I will argue that whereas prefiguration, and prefigurative translation, reflected the mood of an age characterized by a belief in progress and the possibility of changing the world in radical ways, our current epoch is one in which a number of factors have led to a general loss of hope and an erosion of confidence in our ability to effect change. In this new climate of despair and alienation, a strategy of what Gaber (2016) calls aspirational translation may be more productive and sensitive to changes in the way many now orient themselves towards the future.

While the argument presented here is not directly based on empirical research, in the sense of collecting and analysing new data, it is informed by the findings of earlier research on the role played by translation in enhancing or undercutting the political objectives of activist groups during the Egyptian revolution (Baker, 2016a, 2016b). This earlier research involved 11 semistrucutured interviews with activists and activist translators operating in Egypt at the time, as well as analysis of some of their extensive output, specifically subtitled documentary videos of events unfolding on the streets of Egyptian cities during the period 2011-2015 (Baker, 2016a). A further source of data comes from the reflections of the activists themselves, as recorded in a volume edited by the author as part of the same project (Baker, 2016b).

In what follows, I continue the exploration of issues relating to the positioning of activist translators in the context of uprisings and protest movements, but with a specific focus on the question of how different orientations to time may influence the choice of political and translation strategies, and may themselves be influenced by the specific conditions under which activists operate, which vary considerably from one region of the world to another. Despite the emphasis on political activism, the relevance of the argument to the field of medicine should be clear. Extending Engebretsen et al.'s call for incorporating in the practice of knowledge translation a more nuanced theorization of translation as "an entangled material, textual and cultural process which inevitably impacts the 'original scientific message"” (2017, p. 2), I would argue that this process must also be seen as firmly embedded in a global temporal context that calls for different approaches to care. Thus, for example, both the illness and the cure offered to Souad, the teenage radicalized Muslim who was healed through a creative process that allowed her to "re-establish ties to the world and to her own body" through art and greater engagement with language (Kristeva et al., 2018, p. 57), are a product of a particular temporal moment that is being experienced globally. This global moment impacts Souad's own orientation-and the orientation of her generation-to the past, present and future and will have played a role in both her radicalization and the success or failure of the cure proposed for it.

Issues relating to different orientations to the future-specifically failure to prioritize the future-are acknowledged as an important factor in non-adherence to long-term treatment in the case of patients with chronic disease (Reach, 2019). Hautamäki's discussion of two time frames that structure clinical encounters and reflect two logics of care similarly points to the importance of understanding the impact of temporality on the delivery of successful treatment. Clinical time adheres to the ideals of evidencebased medicine and "frames diagnosis and treatment as a linear and task-oriented path" to cure (2018, p. 43), whereas experienced time "relates to the rationality of care and self-care and the embodied experiences of the actors ... [and] to a processual time frame where the changes in the patient's experiences with mood swings forces changes in the interventions" (Hautamäki, 2018, p. 44). Any conceptualization of translation-whether in the sense of knowledge translation or of interlingual translation between patients and physicians-must therefore engage with the issue of temporality, not only in terms of "the singular biography and life context of the individual patient" (Kristeva et al., 2018, p. 56) but also in terms of how entire generations of patients orient themselves to the past, present and future. In other words, it has to relate to "the messy temporal space in which humans live and where sickness and healing actually occur simultaneously" (Kristeva et al., 2018).

\section{Time and translation}

Time is a concrete phenomenon that we can objectively measure in units such as seconds, minutes and hours, which in turn are measured in relation to other concrete phenomena such as sunrise and sunset. Nevertheless, even at this concrete level our experience of time is mediated by instruments, such as calendars, diaries and clocks, and it is largely such mediating instruments that allow us to acquire a shared sense of time. More importantly, concrete or otherwise, time and the passage of time are ultimately experienced and interpreted subjectively. This is particularly clear in the way different people interpret momentous events and what they make of them, as in the following example.

Basma Alsharif and Philip Rizk, two Cairo-based activist film makers, were interviewed in February 2019 about a new project they had just launched, entitled 'This World Is Strange' (Alsharif and Risk, 2019a, 2019b), a reference to Sun Ra's 'Trying to Put the Blame on Me', which features the poignant lines: "This world is strange/Strange world to me/What is its meaning?, I feel alone/So all alone/Like a different kind of being". The project involves holding workshops in different places to produce collective, critical translations into Arabic of radical foreign films and other material, followed by "discussions, screenings and readings centered around the translated materials" (Alsharif and Rizk, 2019a). It is being undertaken at a point in time when many people in the region are experiencing the post revolution period as depressing, indeed debilitating, with the current regime in Egypt allowing very little space for any form of initiative to be effectively pursued, and with thousands of activists still being imprisoned, tortured or 'disappeared'. In response to a question about how this new project fits into their trajectory as activist film makers whose work "has always been guided by the need for solidarity across communities of struggle, particularly in relation to Egypt and Palestine" (Alsharif and Rizk, 2019a), Basma Alsharif, a Palestinian from Gaza, justified starting a new radical cultural project specifically in Cairo, at this particular moment in time, as follows:

One of the aspects that drew me to stay in Cairo this time around is linked to a similar condition I experienced in Gaza. The moment just after attacks end are the hardest. It is harder than war itself. There is something reassuring about survival, about adrenaline, about knowing that the entire world is watching what is happening to you in the midst of a disaster. The moment that disaster has ended or calmed down, and there is only rubble left to pick up and damages to be assessed, that is a far less sexy moment to be a part of. I remember seeing all the journalists leave Gaza and how clear it was that the spotlight was going to shift to the next disaster, the next headline, and recognizing a kind of heavy weight in those who would have to remain to pick 
up the pieces. Cairo seems to be in a similar state right now, and rather than understanding it as a lull, a depression one could very easily sink into and indulge in, it feels like an important moment when work should be done. (emphasis added)

What we make of a temporal moment or any dimension of time and how we react to it, then, is ultimately subjective. What one person experiences as a debilitating moment another sees as a moment full of potential and one that demands action rather than despair and passivity. Beyond specific moments and specific spaces such as the post revolution period in Egypt, the subjective experience of time also relates to how we orient ourselves towards the three temporal domains that define our existence: the past, the present and the future. In what follows I argue that how we orient ourselves to these three domains has implications for political as well as translational strategies, and that this is true not only at the level of individual experience but also, and more importantly, in terms of the collective experience of generations.

In an article on various processes of anticipation that liberal democracies adopt to act on undesirable futures, leading to measures such as bombing Iraq and Afghanistan to prevent a perceived future threat, or culling bird populations to prepare for a future attack of avian flu, Anderson (2010, p. 780) reminds us that "the future as an imminent/transcendent End of the World was central to the authority of monotheism ...; the future as indefinite, open and perfectible enabled accounts of progress ... [and] the future as a mystery underpins forms of iconoclastic utopianism". Each of these orientations, and they are obviously not the only ones, concerns how 'the future' is conceived by people living in particular periods of time and particular locations, and how it is assumed to relate to the past and to the present.

As with all social actors, the way activists and activist translators see the present and perceive the future has implications for the strategies they adopt as they pursue their various goals in life. The project outline for 'This World Is Strange' (Alsharif and Rizk, $2019 b)$ specifies that "vernacular translations will be proposed to participants [in the planned workshops] as both a practical and ideological endeavor". In the interview cited above (Alsharif and Rizk, 2019a), Philip Rizk offers the following explanation to support the decision to adopt the various spoken dialects of the region rather than Modern Standard Arabic, the variety of language used by educated Arabs in formal settings:

Within the paradigm of a pan-Arabist imagined community one could ... say ... that the latest colonizer in our midst would aim to sever a sense of community among Arabs by restricting their access to a shared language .... Today, this logic has lost all meaning, given that Arab states are busy backstabbing each other and the myth of panArabness has long been laid bare.

Rizk's explanation makes sense in terms of the huge disjuncture between the current realities of the region and the now defunct project of Pan-Arabism and Arab unity, which saw its heyday under the Nasser regime in Egypt in the 1950s and 1960s. One important aspect of the Pan-Arabism project was the need for all Arabs to adopt Modern Standard Arabic as a shared language. Adopting the spoken dialect of whatever country the workshop is held in-Jordan or Algeria, Iraq or Egypt-and subtitling films in that dialect is justified here on the basis that rather than "tearing nations apart", using different dialects merely reflects the current realities of the region, where the Pan-Arab project is dead, and where people do speak different dialects. Modern Standard Arabic, moreover, "remains largely inaccessible but to a minority of Arabic speakers, with relatively few boasting complete command of it". In this sense, Rizk argues, "vernacular translations can address solidarity regionally [because they] can support currents of solidarity that are not enabled by dominant practices in subtitling and translation in the region" (in Alsharif and Risk, 2019a).

This argument betrays a particular orientation towards the past, present and future that I attempt to flesh out in more detail in the remaining sections of this paper. Briefly, it reflects the feeling that the past is in the past, the future is extremely uncertain, and the weight of the present is such that we have to respond to it as we experience it and do our best to cope and effect what changes we deem possible, based on current realities rather than on some utopia we hope or think we can bring into being at a future date. This is a key difference between prefiguration and aspirational translation, as I argue in the section titled 'Aspirational translation' below. In the meantime, it is important to acknowledge that neither strategy-using vernacular or Modern Standard Arabic in subtitling and translating radical material-is without adverse implications. All activist strategies raise inescapable tensions and contradictions, particularly in a fraught political environment. In this specific example, adopting spoken dialects for subtitling and possibly even translating radical written material into spoken Arabic ${ }^{1}$ may well empower local communities, and does reflect the current fragmentation that characterizes the region. It also avoids engaging in the pretension that there is still an Arab community as such, and in this sense is more honest. Arguably, however, it does not make the project of connecting communities of struggle across the region necessarily any easier. It remains very difficult for an Egyptian, for instance, to follow subtitles written in Moroccan or Yemeni Arabic, and vice versa. These tensions are not specific to translation; they are characteristic of all areas of life, and are deeply embedded in and restricted by the temporal and spatial setting in which activists operate. Hence, for example, while the internet and social media have undoubtedly allowed communities of struggle across the world to connect and mobilize in unprecedented ways, the temporal logic of these technologies also disrupts some of the core principles of global movements of action, such as participatory decision making, which requires longer and more flexible time windows, in part because activists are located in different regions of the world and may be separated by up to $12 \mathrm{~h}$ of concrete time (Polletta, 2002; Kaun, 2020). The temporal logic of social media and the Internet therefore poses challenges to processes of deliberation and participation even as these same platforms enable communities to connect in unprecedented ways.

Perhaps, going back to Alsharif and Rizk's idea of using spoken varieties of Arabic in subtitling films, the tension may be partly resolved by refraining from adopting a single, fixed strategy of translation in all contexts, and using instead a range of complementary strategies to respond to the complexities of the temporal moment. For example, in critiquing the use of hegemonic English as a priority lingua franca into which practically all Arabic documentary videos are subtitled, a practice that was adopted by collectives like Mosireen during the Egyptian uprising, I argued (Baker, 2016a) that solidarity is needed most urgently among communities that are struggling in places like Ethiopia, Kashmir and Sri Lanka, very few of whom have sufficient command of English to understand the nuances of an unfolding, complex political uprising. Nevertheless, in an activist conference I organized in Cairo in March 2015 (The Only Thing Worth Globalizing Is Dissent: Translation and the Many Languages of Resistance), ${ }^{2}$ English and Arabic (but mostly English) were adopted as the official languages of the event, with simultaneous interpreting provided only for plenary sessions because of cost restrictions. The conference was attended by many members of the collectives I critiqued for privileging the same hegemonic 
language, but also by many activists and activist translators from across the world, including Turkey, Taiwan, India, Italy and the UK. These activists would not have been involved if the conference had been conducted only in Arabic, nor in Arabic and another language such as Turkish or Kurdish. One of the positive outcomes in this case was that Turkish, Indian, Taiwanese and other activists who attended the conference went back to their communities and initiated and circulated a series of videos about the Egyptian uprising subtitled into a range of languages such as Hindi, Urdu and Turkish, ${ }^{3}$ in which these videos were not previously available. The work of solidarity, in other words, cannot be promoted by dogmatic adherence to a single strategy in all contexts, precisely because time and space are not fixed or totally objective phenomena: they impact and are impacted by the actions of human subjects, including activists and translators.

Nevertheless, although there is no escape from the tensions that beset any attempt to effect change, and no escape from the realities of the moment, it is possible to reflect on them and adapt activist strategies to address the specific pressures and exploit the opportunities of that moment. Whether activists attend more to the immediate realities or to a vision of a better future they want to bring into being is one of the main differences between prefiguration and aspirational translation, to which I now turn.

\section{Prefiguration: Organizational and semiotic}

Prefiguration, a political strategy that has received many complementary definitions and much critical attention, is the subject of a vast literature, primarily in social movement studies (Maeckelbergh, 2009a, 2009b, 2011; Rohgalf, 2013; Luchies, 2015; Yates, 2015; Ishkanian and Peña Saavedra, 2019), but also to some extent in fields such as political psychology (Trott, 2016) and organization studies (Reinecke, 2018). Aspirational translation, on the other hand, is a concept that awaits a definition, and one that does not seem to be anchored in a specific discipline despite being clearly focused on the practice of translating, in both its metaphorical and concrete, textual senses. It is discussed, without being defined as such, in one paper by Sherief Gaber (Gaber, 2016), a member of the Mosireen collective of film makers who were active during the Egyptian Revolution (2011-2013). Gaber is a researcher and urban planner who had never written on translation before and has not written on it since; he is therefore unlikely to contribute further to the elaboration of this concept. I attempt to flesh out a definition in the section entitled Aspirational Translation from his brief discussion of this strategy and tease out its implications for the current historical moment. I begin here with a discussion of prefiguration, the strategy with which I wish to contrast aspirational translation in the context of different experiences of the present and their implications for conceptualizing the future.

In the literature on social movements, prefiguration is often associated with anarchism and defined as "a political practice in which social movements attempt to bring about a desired goal or vision for society by enacting and embodying that vision themselves in their own daily organizing" (Maeckelbergh, 2020; emphasis added). As is evident in this definition, for social movement scholars prefiguration is strictly a question of enacting organizational and structural processes that embody the desired future, typically by adopting horizontal, non-hierarchical modes of working together. Maeckelbergh (Maeckelbergh, 2020) confirms that despite its rootedness in anarchist thought, which she asserts did not itself reject power hierarchies in social life, "today prefiguration refers specifically to the creation of internal movement organizational forms that reflect the ideal and goal of creating a less hierarchical society. In practice this means the elaboration of complex systems to ensure egalitarian decision- making". This definition does not allow for extending prefiguration to textual or semiotic means of articulating the kind of future that activists wish to bring into being. In translation studies, however, Baker (2016a, 2016b) has argued for the potential applicability of prefiguration as a textual and semiotic strategy in the context of the 2011 Egyptian uprising, citing examples from the work of collectives such as Mosireen and Words of Women from the Egyptian Revolution and the volunteer translators who subtitled their videos into a variety of languages. Taviano (2016) attempts to explain a wide range of verbal and non-verbal strategies adopted by activist hip hop artists in Sudan as prefigurative modes of translation. The most extended, critical discussion of the semiotic and textual realization of prefigurative strategies to date, however, is provided in Buts (2019a, 2019b). Key to both definitions - organizational and semiotic-is an emphasis on experimentation as a cornerstone of prefigurative politics. From the organizational perspective, prefiguration supports an understanding of movements as "laboratories for experimenting with ways of imagining and living otherwise" (Haiven and Khasnabish, 2013 , p. 479); as semiotic practice, it entails a "willingness to explore alternatives, to create anew, to depart from and subvert conventions" (Baker, 2016a, p. 6). ${ }^{4}$

Anderson's (2010) study of various types of anticipatory action and how they imagine and fashion the future can shed light on the different ways in which organizational and semiotic strategies of prefiguration are realized. Of particular interest are the three practices through which he suggests "futures are made present while remaining absent" (Anderson, 2010, p. 783): calculation, imagination and performance. Calculation "renders complex future geographies actionable through the numericalization of a reality to come" (Anderson, 2010, p. 784) and does not concern us here. The other two practices, imagination and performance, may help clarify the difference between the social movement studies, organizational understanding of prefiguration and more recent attempts to extend that understanding to the textual and semiotic realm in translation studies. For social movement scholars, prefiguration seems to be understood only as a practice of performance, of "making futures present experientially" (Anderson, 2010, p. 786), by means of embodiment, in Anderson's model. Typical techniques of invoking the future through performance include simulations and exercises, which "involve staging a specific possible future (whether in live or artificial time), and participants then playing or performing a set of roles" (Anderson, 2010, p. 786). Social movement activists perform the ideal future society by simulating its modes of organization and processes of decision making in the present. Maeckelbergh thus insists that "prefiguration is something people do" (2011, p. 3; original emphasis), and hence that while "[h]ow 'horizontality' and 'diversity' work is very hard to explain in words", this is nevertheless "obvious to people who experience it" (Maeckelbergh, 2011; emphasis added). Similarly, reporting on activists involved in the Occupy movement, Teleb (2014) asserts that "they sought to experience what participatory democracy would be like. ... They wanted to see what they were never taught in civics class. What does it mean to deliberate? What does it 'feel' like? In short, they wanted to ' $d o$ it themselves"' (emphasis added). Examples of prefigurative projects include the media outlet YMA (Youth Media Action), where activists "set up a prefigurative space for themselves in the form of a physical and digital space where they convene to collectively produce and distribute media made by and for youth" (Kulick, 2014, p. 367; emphasis in original).

By contrast, scholars of translation see prefiguration as the work of imagination in Anderson's terms, where "making the future present becomes a question of creating affectively imbued representations that move and mobilize" (2010, p. 784); these representations take the form of images, symbols and narratives 


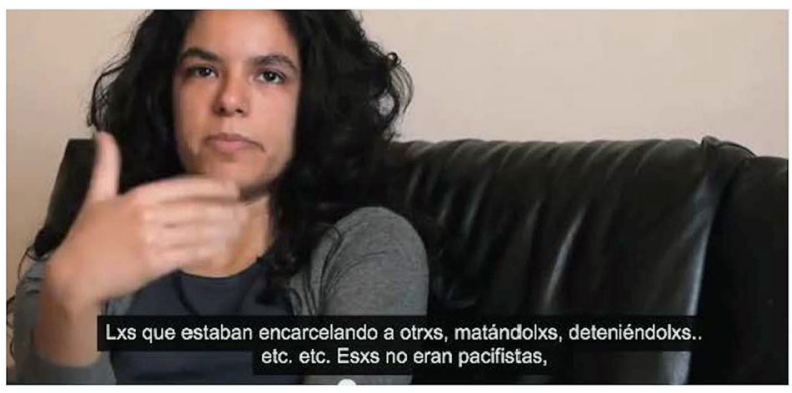

Fig. 1 Words of Women from the Egyptian Revolution, Episode 1: Aya Tarek; screenshot reproduced with permission from Leil Zahra-Mortada, founder of Words of Women project.

(Anderson, 2010, p. 785). Taviano (2016, p. 286) cites examples from Sudanese hip hop groups who subvert the conventions of naming and "appropriate and deconstruct the term 'revolution' while providing a local interpretation of what it involves, based on their own experiences". Baker (2016a) discusses an interesting strategy adopted by the subtitlers of Words of Women from the Egyptian Revolution videos into Spanish, which involved consistently replacing the masculine and feminine endings os and as in Spanish (as in the indefinite pronoun otros, otras) with $x \mathrm{~s}$ (otrxs) (Fig. 1), in an effort to subvert the gender binary reinforced through grammatical marking in language.

Given the limited literature on the semiotic dimension of prefigurative politics, there is a relative paucity of examples, but the difference between this mode of intervening in the future and the organizational emphasis in social movement studies is clear. Ultimately, however realized, prefiguration implies that the future can be shaped by our actions in the present, and that we-individually and collectively-have the power to shape it. This level of certainty in a brighter future and the intense focus on how to bring it about is missing from Gaber's (2016) discussion of aspirational translation, as I will demonstrate shortly. But first, the difference between the two approaches, prefiguration and aspirational translation, needs to be understood in the context of changing attitudes to the future as elaborated in Berardi's work (2011, 2012a, 2012b, 2017/2019).

\section{Prefiguration in the century with no future}

I take the expression "the century with no future" from Franco Berardi's volume After the Future (Berardi, 2011), where he uses the phrase repeatedly to refer to the 21 st century, as opposed to the 20th century-that "century that trusted in the future" (Berardi, 2011, p. 12), the century of the 'moderns', "those who live time as the sphere of a progress towards perfection, or at least towards improvement, enrichment, and rightness" (Berardi, 2011, p. 18). The 20th century had trust in the future "because it trusted in scientists who foretold it, and in policy makers able to make rational decisions" (Berardi, 2011, p. 39). The 21st century, by contrast, is the century of speed, density, virtuality, disorientation, alienation, the loss of connections and lack of embodiment, leading to a pervasive sense of panic and an erosion of confidence in the possibility of a brighter future.

Berardi's account of what he calls the century with no future is wide ranging and touches on many aspects of the way our societies function today. The editors of After the Future sum up his main argument as follows in their Preface:

The analytic, psychological, and libidinal structures of 20th century revolutionary politics were beholden to the temporal form of the future-it even gave the name to the first movement of the avant-garde: Futurism. The future was on the side of the revolution. It was a great and empowering myth, but few believe it any longer: the future is over.

Another summary which similarly stresses the political implications of Berardi's view of the 21st century appears in an article from the radical Internet-based ROAR Magazine ${ }^{5}$ (Roos, 2015):

For all its tragedies and failures, at least the old left was once driven by hopes and visions of a better future. Today, all such aspirations seem to have been abandoned. As Franco 'Bifo' Berardi has astutely put it, the future has been cancelled-and the left, unmoored from its post-capitalist imaginary, has been cast hopelessly adrift in the process.

Berardi's analysis of the 21st century's outlook on the future and the roots of the creeping pessimism and depression that characterize the current epoch is highly detailed. The main emphasis is on what he refers to as semiocapital, meaning "a form of social production which is essentially focused on the production of signs, of 'semio"' (2012a). Semiocapitalist production, he argues in After the Future, "captures and connects cellularized fragments of de-personalised time; ... purchases fractals of human time and recombines them in the web" (2011, p. 26). Semiocapitalism does not produce material goods; it produces semiotic goods in the form of "signs, figures, images, projections, expectations" (Berardi, 2011, p. 77), as well as "psychic stimulation" (Berardi, 2011, p. 73), at a phenomenal speed and with such density that the human mind becomes overwhelmed and is no longer able to process the flood of information it receives (Berardi, 2011). This has at least two interconnected implications for the possibility of political action.

First, revolutionary action has traditionally relied on disruption, but in this new environment of speed and excess disruptions no longer produce revolutionary results. On the contrary, "as the density and speed of information becomes too high to be elaborated and subverted by a revolutionary group, the disruption tends to be morphostatic, only reinforcing the pattern which has produced the disruption itself" (Berardi, 2012b, p. 143). Revolution and revolutionary symbols become a commodity that can be repackaged and sold as semiotic goods, as Hamilton explains with reference to the aftermath of the Egyptian uprising (2016, pp. 242-243):

Obama, his hypocrisy never to be outdone, declares "we must educate our children to become like young Egyptian people". Vodafone proudly displays his words in Cairo airport. The revolution now is a commodity. It sells us Pepsi and bank accounts and future presidents. The language and image of the revolutionary youth are colonized, commodified, sanitized, and the Fall of Mubarak is ingested, translated and transmitted as something easily comprehensible, something 'good', something in the past, something over.

Speed and density also impact our "very perception of others as embodied, as living organisms" (Berardi, 2011, p. 40), an effect connected to the second implication of semiocapitalism for political action, which concerns the replacement of "physical things" with "immaterial signs" as "the main object of capitalist valorization" (Berardi, 2011, p. 77). This replacement has an impact on subjectivity because of the "bodily re-composition of cognitarian labour" (Berardi, 2012a) in digital space. Solidarity becomes impossible because it loses its physical, territorial basis: "You cannot have solidarity between fragments of time: you need people, you need bodies, you need what has been dissolved" by semiocapitalism (Berardi, 2012a). Time does not stop while all this is happening: it continues to unfold, but our collective and 
individual trust in a better future disappears and is replaced by a terrifying panic and a sense of alienation and hopelessness triggered by excessive speed, density and virtuality. What does this new orientation towards the future and the lack of confidence in the possibility of shaping it in tune with our aspirations mean in terms of activist and activist translation strategies, and how does it relate to prefiguration and a potential definition of aspirational translation?

Prefiguration assumes that we can act on the future in positive ways: ${ }^{6}$ in a manner that can lead to greater justice and equality for all. Powerful institutions and individuals who pursue their own, often unjust and highly destructive ends, also attempt to configure the future by acting in the present, but they do so for very different reasons, and in ways that foreclose change. Specifically, they adopt approaches that ultimately ensure that the future reasserts and reinforces the past, rather than imagining it in new ways or leaving it open to wider possibilities. The official strategy of pre-emption, on which policies such as profiling are based, adopts an inherently conservative vision of the world by assuming that how a person behaved in the past or the kind of environment or locale they were born into necessarily predict how they will behave in the future. Pre-emption therefore reinforces established views of the world, projecting them into the future, and acts on this basis in the present in ways that ensure that future is realized. It forecloses any alternative imagining of the future. Berardi (2017/2019) suggests that pre-emption today has even more sinister goals and more serious, irreversible effects. It is a political strategy that "prescribes in a deterministic way the future form of the organism by the insertion of biotechnical or techno-social mutations" with a view to "automat[ing] future behaviour" (Berardi, 2017/2019, p. 12).

Prefiguration attempts the opposite of this institutional strategy of pre-emption, despite similar levels of confidence in the possibility of anticipating and changing the future. Specifically, revelling in experimentation and creativity, it makes no attempt to fix the future, even by formulating a set of demands to be met by the institutions against which activists rebel. It also leaves the past behind and looks forward to the future, acting in the present in ways that might realize a particular vision of a better future rather than reinforcing models inherited from the past. Prefiguration is therefore rooted in the present but orients itself towards the future. It has little or no relationship with the past, except as a reference point against which a better future may be asserted. In this sense it partakes of the twentieth-century narrative of progress and reflects the kind of faith in a better future, or the myth of the future, that Berardi $(2011$, p. 13) attributes to the rise of modern capitalism, the expansion of the economy, and the scientific revolution. Berardi argues that all strands of modern political theory-including anarchism, to which prefiguration is usually attributed-"share a common certainty: notwithstanding the darkness of the present, the future will be bright" (Berardi, 2011). The two reassuring qualities about this myth of a brighter future are the belief that we are able to know and predict the future, in part because we can trust science to discover more laws of nature and develop the necessary instruments for controlling it; and the belief that "the future may be transformed by human will, by industry, economic technique and political action" (Berardi, 2011, p. 39). This confidence in our ability to have an impact on the future is clearly reflected in the idea of prefiguration-the idea that we can intervene and make things better by acting now in particular ways.

But Berardi insists that "our post-futurist mood is based on the consciousness that the future is not going to be bright" (2011, p. 17 ), and in this sense, the sense of the future not as temporal unfolding, a direction of time, but as a psychological perception, a mood, "the future is over" (Berardi, 2011, p. 13). It is over because although "we know that a time after the present is going to come ... we don't expect that this time will fulfill the promises of the present" (Berardi, 2011, p. 17). If Berardi is right, then the concept of prefiguration must lose at least some of its appeal with the collapse of the idea of a potentially better future and the confidence invested in believing that we can act on that future. Increased insecurity, precarity, virtuality and a growing sense of a lack of control over our lives may be driving us to look for comfort in the past rather than in the future, making nostalgia a more attractive proposition: the past becomes a safer, more comforting ground to relate to in order to cope with a challenging present, as evident in Alsharif and Rizk's statement (2019a) that they hope their translation workshops can contribute to "shifting our focus towards the present by learning from those who have been here before, elsewhere".

As this quote suggests, contemporary sources of anxiety also leave us preoccupied with surviving in the immediate present. The weight of the present overwhelms the imagination and leaves less room for thinking about the future. Although human beings cannot but hope and dream of improvements in their lives (or recompense in another life), and cannot help but revolt when the severity of injustice becomes too much to bear, I would argue that the picture Berardi paints of the current moment is shared by many, even as they risk their lives to effect some change, especially in those parts of the world where people feel doubly disempowered because of the legacy of colonialism and the severity of state repression. Hamilton (2016, p. 242), the Egyptian activist, writer and film maker cited earlier, expresses a similar view of the future to Berardi's:

We live in a time without imagination. In a global moment without possibility. We live in the end times, at the peak, the pinnacle, preparing for the fall. We live on the brink of annihilation. We live beyond our means. We live without direction.

For those advocating prefiguration, then, it is important to bear in mind that activists who have to cope with severe forms of repression and high levels of destitution, in addition to the alienation and disorientation produced by semiocapitalism, are unlikely to envision an ideal future, nor have time-or indeed appetite-for experimenting with different ways of making that future present. If the weight of the present is such that we are forced to invest all our energies in coping with it, our vision becomes constrained and hence can provide no basis for experimentation. Experimentation assumes that one is able to imagine a different future, but as Abdalla (2016, p. 42) points out, again with reference to the post-revolution experience in Egypt,

If you cannot see or do not believe in what might become, the focus point of your political interest becomes ever more based on a sense of structures imaginable from the present, and so the closer the point of submission to the way things are. But if the way things are is truly unlivable-above all, as a present for the future-eventually you have no choice but to explode no matter what, ... because the entrapment of an unbearably awful present covers generations to come, not only your life, or those of your children, but possibly far beyond.

These reflections are drawn from experiences that are far removed from the context of the wave of protests in Europe and the US typically associated with prefiguration, such as the Occupy, 15-M/Indignados and other movements that came to be known as 'movements of the squares'. This wave of protests started in the Arab World, specifically Tunisia and Egypt. Nevertheless, both the triggers of protest and the level of violence used in repressing them were much more severe in this region 
than in Europe and the US, and more serious even than austerity - that being the main trigger of protests that have received the lion share of interest from scholars in the North (Razsa and Kurnik, 2012; Rohgalf, 2013; Flesher Fominaya, 2014; Sharma, 2014; Reinecke, 2018; Kavada and Treré, 2019; among many others). Although Berardi's account of the century with no future is not restricted to any specific regions or classes, I would argue that differences in the lived experience of people in different parts of the world further mediate their ability to envision the future prefiguratively, if at all. As Appadurai (2013, p. 299) asserts, "the future is certainly not a neutral ... space". For people "in conditions of poverty, exclusion, displacement, violence, and repression", he rightly points out, "the future often presents itself as a luxury, a nightmare, a doubt, or a shrinking possibility"; it is experienced as "a trauma inflicted on the present by the arrival of crises of every description".

\section{Aspirational translation}

The strategies proposed by Gaber (2016) for aspirational translation, and the way he talks about this form of translation, reflect the current mood and orientation towards the future as outlined by Berardi and implied in particularly stark terms in the reflections of activists, like Hamilton and Abdalla, who have direct experience of recent violent events in countries such as Egypt. As an urban planner, Gaber is keen to develop a terminology for talking about the city that is not simply imported from the North but is rooted in the immediate realities of the Egyptian capital, realities which are far removed from those of New York, London or Paris. The closest he comes to a definition, which does not materialize until the last two paragraphs of the article, makes aspirational translation sound rather close to prefiguration at first glance. Given the lack of a clear, formal definition of the concept, this is worth quoting in full $(2016$, p. 105):

Public spaces have been denigrated and excluded from our vocabularies. The issue here is thus one of aspirational terminology, perhaps, of actively creating terminology to describe the spaces we desire, spaces we want to bring into existence. The creation of such an aspirational terminology would take as its starting point the everyday language of the streets, the language used to describe those streets, and would imbue it with both political potential and theoretical sophistication. ...

Even if the outcomes of a socially just city are the same in Chicago as they are in Cairo, the cities are vastly different, as are the tools and resources that are available to build more just cities. An aspirational language of the city recognizes this, and recognizes that local terms alone are not sufficient, but their deployment is a necessary condition for helping to kindle the imagination and create possible spaces within the existing city. Uncovering and developing new terms for the Egyptian city-or any city-is in this sense a process of uncovering the mechanisms and tools that can create leverage to change the city.

In practice, however, and in the extended discussion leading to these final two paragraphs of the paper, aspirational translationunlike prefiguration-is not only firmly rooted in the present, and to some extent looks towards the past for inspiration, but it is overwhelmed by the present (Gaber, 2016, p. 106, no. 8):

... in a city which in the last fifty years (at most) has seen a radical transformation of its very nature, not to mention an explosion in built area and population, it is clear that the compressed present holds overwhelming sway over the city.
And indeed the examples Gaber gives for the kind of terminology that he believes should be adopted make it clear that his attention is totally focused on the present realities and on reaching out to people embedded in those realities in order to empower them-not through any form of experimentation but merely by working with them to develop a shared language with which to talk about their realities in an idiom they recognize and can relate to. Aspirational translation thus foregrounds the need to reconnect with the lived experience of laypeople, in this case people locked in poor, overpopulated, concrete urban spaces who struggle to merely survive from day to day.

In terms of its relationship to the past, although Gaber claims that he would not attempt to suggest using terms from the distant past, both because he does not have the expertise to uncover such terms and because the city has changed so radically that it bears little relationship to its medieval past, he does repeatedly invoke the past, perhaps the less distant past. For instance, in outlining the main issue in the abstract of the article $(2016$, p. 97), he points out that "Arabic terms often have no ready equivalents in English. These terms have older histories and roots within Egyptian culture, and many are now attempting to deploy them to advance contemporary social justice demands". Deploying terms from the local past is thus confirmed as one strategy of aspirational translation. The past remains relevant.

Gaber offers a concrete example of going back to classical Arabic for alternatives to urban, a term/concept imported from the North and normally translated as 7adari (the same term used to translate metropolitan) or madiini (of the city). ${ }^{7}$ Urban, Gaber argues, reflects the town/country split common in Europe rather than the realities of a country like Egypt. He therefore suggests translating urban as عمر ان/3umraan, because 3umraan is closer to the concept of built environment, which encompasses not just urban areas but also other areas of human settlement, including rural areas. It originates from Ibn Khaldun's Prolegomena, which contrasts the built environment with unsettled areas and desert. Gaber argues that "[r]ecovering these classical words and deploying them in critical and professional contexts allows us to reconfigure the analytic units used to describe the city and its social formations: it allows us to develop alternative configurations to those derived from Northern histories of property and urbanism" (2016, pp. 103-104). Unlike prefiguration, then, aspirational translation does not disregard the past: the past is an important resource with direct relevance to the present.

At the same time, while not dismissing the prospect of positive change, aspirational translation does not orient itself to the future and does not exude confidence in it in the same way as prefiguration. Gaber does talk about the need for a new language to "document new phenomena as well as advocate for change" (2016, p. 99; emphasis added), but not a language or practices to anticipate the future or bring it into being. Rather, the function of this new language seems to be envisaged as enabling its users to hold on to what little they have left after decades of repression and assault by the ruling regime. It is necessary not in order to anticipate a different future but to resist the language of the state, which continues to assert itself and its grip on spaces by using its own vocabularyand the legal system - to refer to the spaces people inhabit in ways that suit those in power. This is evident in the widespread official use of the term araadi al dawla (the state's lands) which "designat [es] public utilities and infrastructure (including streets and sidewalks) as military installations, with transgressions against them carrying the threat of military trial" (Gaber, 2016). The effect of enforcing this term is that public spaces come to be treated as "'facilities' and 'installations', not public space, much less spaces of sociability, interaction or community" (Gaber, 2016, p. 102), and the vocabulary of what would otherwise be understood as public 
space becomes "incorporated into a security/strategic language" (Gaber, 2016). Reviving a language from the past to describe the realities of the present can serve as a strategy to compete with the official language and assist in advocating for (modest) change-but not necessarily in anticipating a better future by creating facts on the ground as prefiguration sets out to do.

The terminological dilemmas that Gaber struggles with are not abstract and do not concern linguistic accuracy or elegance. The idea of aspirational translation relates to developing a critical terminology which can support effective advocacy for social justice in the city. Gaber, and other urban specialists in the region, attempt to find terms with which they can rehabilitate concepts such as 'public space' in Arabic; the terms they use have to be comprehensible to people on the street and resonate with their lived experience of the city. They must also be suitable for creating a shared language across the region, to assist with the work of advocacy. ${ }^{8}$ Aspirational translation, as envisaged by Gaber, is thus rooted in the local and privileges the lived experience of laypeople, not only in order to be able to converse and work with them on critical urban projects, but because the terms used by laypeople who live in the kind of neighbourhoods activists like Gaber target embody a communitarian ethos that is missing from the imported vocabulary of western urban scholarship. Gaber (2016, p. 104) thus argues that

by focusing on the space generated by the languages of their fellow citizens, professionals and activists can direct their efforts towards enhancing those issues that people most care about, and creating change not in abstract sites unconnected to lived experience but in the concrete divisions and phenomena that people natively perceive as they experience the city.

It is in this sense too that aspirational translation privileges the present, much more than the past and the future. And it is in this sense that it perhaps reflects the waning of the myth of a brighter future and the confidence in our ability to bring that better future into being by experimenting with novel and utopian ways of living together in the present, or with semiotic innovations that anticipate a better future prefiguratively. The present in which the concept of aspirational translation was conceived is too pressing, too challenging to ignore. It is populated by large swathes of people whose confidence in their ability to change the future has steadily crumbled under the weight of the many, increasingly violent setbacks and traumas of the recent and not so recent past, especially in regions like the Arab World and much of Africa, thus adding a further layer of hopelessness to the sense of alienation and panic that Berardi outlines as a feature of the current epoch worldwide. For activists living in and attempting to respond to such harsh realities, experimentation is a luxury they cannot afford to indulge in. This is evident in the difference between the kind of strategies Gaber advocates for aspirational translation, specifically his emphasis on using the language of laypeople, and the type of highly marked prefigurative strategies adopted by Words of Women from the Egyptian Revolution in their Spanish subtitling of gender-marked language (Fig. 1 above). ${ }^{9}$ Experimentation also comes across as almost obscene in the context of intense trauma and suffering, as Hamilton implies in an interview reported by Baker (2018, p. 461):

... you've got some father or mother crying over their kid who's been killed and they're saying how they're going to get their rights, and it's not the place for you to come in and video art and mess around... it's not your job to come in and make an Omar Hamilton film of their grief.

Finally, the mobilizing strategies of aspirational translation and its orientation towards the present and future recall Cassegård and Thörn's analysis of recent waves of protest associated with the environmental movement, which they suggest "seem neither to be nourished by a strong sense of hope, nor of a future disaster, but a sense and an idea that the catastrophe is already ongoing" (2018, p. 562; emphasis in original). Interestingly, Cassegård and Thörn associate this shift in perspective specifically with the Global South, areas of the world which have suffered the highest levels of repression and destruction, and "where there appears to be an increasing preoccupation with catastrophe, not so much as a future threat but as a present reality or a future that can no longer be averted" (Cassegård and Thörn, 2018, p. 563).

\section{Concluding remarks}

Berardi begins his latest book, Futurability: The Age of Impotence and the Horizon of Possibility, with the statement: "I'm not going to write about the future, again. I'm not going to write about nofuture, either" (2017/2019, p. 1). As the subtitle of the book indicates, while still stressing the idea of impotence and our loss of ability to impact the future, he strives to provide a vision of a possible way out of the world's current predicament. His starting point is acknowledging that alternative futures are always inscribed in the present, and that the prospect of effecting change therefore cannot be totally ruled out-the future is not over yetbut that prospect is ultimately subject to the tension between three elements: possibility, potency and power. Liberation, he argues, is but a mere possibility, one that "needs potency in order to be actualized" (Berardi, 2017/2019, p. 9) and that is constrained by power's attempts to restrict the range of possibilities available to us.

Time and technology remain the central themes. In an interview published in the online 032c Magazine, Berardi (2017) attributes our current impotence to the fact that the "temporality of politics, of criticality, of decisions has been outpaced by the temporality of the info sphere. The info sphere is too fast, too thick for the political understanding, the political critique, the political reason". The only way out of this desperate situation is to effect "a deep transformation of the technological machine". But millions of workers worldwide contribute to maintaining and expanding this machine, and hence, he declares, "the selforganization of the cognitive worker is the way out".

Berardi's more recent approach to the future is neither prefigurative nor aspirational in the terms I outlined earlier. Perhaps it is a combination of both: he remains overwhelmed by the challenges of the present but nevertheless strives-in his latest book at least-to envision a way out based on a relatively longterm vision of the future, and to encourage others to begin working towards that vision now, in the present. But he is ultimately not very hopeful, declaring at various points that "political hope is dead. Forever" (2017/2019, p. 39), because "[t]he systemic conditions for democracy have been cancelled by prevailing irreversible processes" (Berardi, 2017, p. 42). Activist translators, like others striving to effect some change, however modest, will continue to negotiate this difficult and fast-changing terrain of the overwhelming present and uncertain future in ways that are subject to the specific, immediate environment in which they operate. Precisely because the future possibilities inscribed in the present are different and the levels of potency and workings of power have always varied considerably from one region to another. Even the environmental apocalypse, as Cassegård and Thörn assert (2018, p. 575), is "socially and geographically uneven" and hence elicits different orientations towards the future and different strategies of mobilization.

Appadurai (2013, p. 298) recognizes that "[f]or the large percentage of the world's population which may be said to function in the condition of 'bare life,' we have not yet found ways to 
articulate how anticipation, imagination, and aspiration come together in the work of future-making". Speaking as an academic, and specifically as an anthropologist, he suggests that the way forward lies in us "commit[ing] ourselves to a partisan position", at least in terms of working as "mediators, facilitators, and promoters of the ethics of possibility against the ethics of probability" (Appadurai, 2013, p. 299), and doing so concretely and in our own fields, not "abstractly or in those domains from which we are most distant or disconnected" (Appadurai, 2013, p. 300). I would argue that translators-as mediators and facilitators par excellence -and those who are interested in engaging with the consequences of how they negotiate the future as they produce the utterances and texts that impact all our lives-have an important role to play in arresting if not reversing the ongoing erosion of those possibilities still inscribed in the present.

\section{Data availability}

Data sharing not applicable to this article as no datasets were generated or analysed during the current study.

Received: 24 October 2019; Accepted: 21 January 2020;

Published online: 11 February 2020

\section{Notes}

1 The use of dialect in formal, written text is particularly uncommon and frowned upon in Arabic.

2 https://globalizingdissent.wordpress.com/.

3 Unfortunately mostly via the English subtitles of these videos. See Baker (2016a) for a critique of the practice of indirect translation via English in this context, and acknowledgement of the restrictions and tensions that motivate it.

4 For a critique of the experimental aspects of prefiguration in the context of Occupy, see Rohgalf (2013).

5 The article forms part of the Genealogies of Knowledge electronic corpus of Internet material, accessible to researchers and searchable through an accompanying suite of software tools. See https://genealogiesofknowledge.net/genealogies-knowledge-corpus/.

6 An interesting variant on this future-oriented form of activism is associated with the environmental movement, which "typically achieved its greatest impact by invoking the terrifying losses that will ensue in the future unless we act to prevent them" (Cassegård and Thörn, 2018, p. 562). The idea of "a better or utopian future" has thus been "less important as a mobilizing tool" for this movement than invoking "fear of the coming catastrophe or collapse" (Cassegård and Thörn, 2018).

7 I follow Gaber here in adopting a system for transcribing Arabic that was developed by Arab bloggers, rather than by scholars of Arabic. In this case, for instance, the numeral 7 represents $ح$ (a heavy $h$ with no equivalent consonant in European languages).

8 This follows the same logic of Alsharif and Rizk's (2019a, 2019b) decision to opt for vernacular translations, discussed earlier.

9 Leil Zahra-Mortada, who founded Words of Women from the Egyptian Revolution and oversaw the subtitling of the videos into Spanish, was heavily involved in the protests in Egypt and played an instrumental role in setting up OPANTISH (Operation Anti-Sexual Harrassment) during some of the most violent months of the uprising (Zahra-Mortada, 2015). Members of OPANTISH, including Zahra-Mortada, risked their lives repeatedly to rescue female protestors who were targeted for mass sexual assaults during the uprising, especially in Tahrir. However, the videos produced by Words of Women from the Egyptian Revolution were shot and subtitled in relative safety and comfort, away from the violence of the uprising. A Lebanese by origin, Zahra-Mortada has lived in European cities, specifically Barcelona and Berlin, for many years.

\section{References}

Abdalla K (2016) Changing frames and fault lines: notes towards a map of revolution's shifting narratives. In: Baker M (ed.) Translating dissent: voices from and with the Egyptian revolution. Routledge, London \& New York, NY, pp. 33-44

Alsharif B, Rizk P (2019a) In order to move forward. Interviewed by Baker M. Camden Arts Centre, London

Alsharif B and Rizk P (2019b) This world is strange العالم ده غريب. Unpublished manuscript

Anderson B (2010) Preemption, precaution, preparedness: anticipatory action and future geographies. Prog Hum Geogr 34(6):777-798
Appadurai A (2013) The future as cultural fact: essays on the global condition. Verso, London \& New York

Baker M (2016a) The prefigurative politics of translation in place-based movements of protest: subtitling in the Egyptian revolution. Translator 22(1):1-21

Baker M (2016b) Beyond the spectacle: translation and solidarity in contemporary protest movements. In: Baker M (ed.) Translating dissent: voices from and with the Egyptian revolution. Routledge, London \& New York, pp. 1-18

Baker M (2018) Audiovisual translation and activism. In: Pérez-González L (ed.) The Routledge handbook of audiovisual translation. Routledge, London \& New York, pp. 453-467

Berardi F (Bifo) (2011) After the future, Edited by Gary Genosko and Nicholas Thoburn, translated by Arianna Bove, Melinda Cooper, Erik Empson, Enrico, Giuseppina Mecchia, and Tiziana Terranova. AK Press, Chico

Berardi F (Bifo) (2012a) Semio-capital and the problem of solidarity. Panel contribution to 'We Have Our Own Concept of Time and Motion', organized by Auto Italia in collaboration with Federico Campagna, Huw Lemmey, Michael Oswell and Charlie Woolley, August 2011. Published online and available at https://libcom.org/book/export/html/45057

Berardi F (2012b) The transversal function of disentaglement. In: Campagna F, Campiglio E (eds) What we are fighting for: a radical collective manifesto. Pluto Press, London, pp. 139-145. (Bifo)

Berardi F (2017/2019) Futurability: The Age of impotence and the horizon of possibility. Verso, London \& New York. (Bifo)

Berardi F (Bifo) (2017) BIFO BERARDI on political impotence and the rise of Global Silicon Valley, interviewed by Sanja Grozdanic, 29 August. https:// 032c.com/bifo-berardi

Buts J (2019a) Political concepts and prefiguration: a corpus-assisted enquiry into democracy, politics and community. University of Manchester, Manchester UK, Unpublished $\mathrm{PhD}$ Thesis

Buts J (2019b) Translation and prefiguration: consolidating a conceptual encounter, perspectives. J Translatol. https://doi.org/10.1080/0907676X.2019.1682626

Cassegård C, Thörn H (2018) Toward a postapocalyptic environmentalism? Responses to loss and visions of the future in climate activism. Environ Plan E 1(4):561-578

Engebresten E, Sandset TJ, Ødemark J (2017) Expanding the knowledge translation metaphor. Health Res Policy Syst 15:19

Flesher Fominaya C (2014) Debunking spontaneity: Spain's 15-M/Indignados as autonomous movement. Soc Mov Stud 14(2):142-163

Gaber S (2016) What word is this place? Translating urban social justice and governance. In: Baker M (ed.) Translating dissent: voices from and with the Egyptian revolution. Routledge, London \& New York, pp. 97-106

Haiven M, Khasnabish A (2013) Between success and failure: dwelling with social movements in the hiatus. Interface 5(2):472-498

Hamilton OR (2016) Moments of clarity. In: Baker M (ed.) Translating dissent: voices from and with the Egyptian revolution. Routledge, London \& New York, pp. 241-244

Hautamäki L (2018) Uncertainty work and temporality in psychiatry: how clinicians and patients experience and manage risk in practice? Health Risk Soc 20(1-2):43-62

Ishkanian A, Peña Saavedra A (2019) The politics and practices of intersectional prefiguration in social movements: the case of sisters uncut. Sociol Rev 67 (5):985-1001

Kaun A (2020) Temporality. In: Baker M, Blaagaard B, Jones H, Pérez-González L (eds) Routledge encyclopedia of citizen media. Routledge, London \& New York (in press)

Kavada A, Treré E (2019) Live democracy and its tensions: making sense of livestreaming in the $15 \mathrm{M}$ and occupy. Inf Commun Soc. https://doi.org/ 10.1080/1369118x.2019.1637448

Kristeva J, Moro MR, Ødemark J, Engebretsen E (2018) Cultural crossings of care: an appeal to the medical humanities. Med Humanit 44:55-58

Kulick R (2014) Making media for themselves: strategic dilemmas of prefigurative work in independent media outlets. Soc Mov Stud 13(3):365-380

Luchies T (2015) Towards an insurrectionary power/knowledge: movement-relevance, anti-oppression, prefiguration. Soc Mov Stud 15(5):523-538

Maeckelbergh M (2009a) The will of the many: how the alterglobalisation movement is changing the face of democracy. Pluto Press, London \& New York, NY

Maeckelbergh M (2009b) Reinventing democracy. Red Pepper. http://www. redpepper.org.uk/Reinventing-democracy/

Maeckelbergh M (2011) Doing is believing: prefiguration as strategic practice in the alterglobalization movement. Soc Mov Stud 10(1):1-20

Maeckelbergh M (2020) Prefiguration. In: Baker M, Blaagaard B, Jones H, PérezGonzález L (eds) Routledge encyclopedia of citizen media. Routledge, London \& New York, NY (in press)

Polletta F (2002) Freedom is an endless meeting. Democracy in American social movements. University of Chicago Press, Chicago \& London

Razsa M, Kurnik A (2012) The occupy movement in Žižek's hometown: direct democracy and a politics of becoming. Am Ethnol 39(2):238-258 
Reach G (2019) Temporality in chronic diseases and adherence to long-term therapies: from philosophy to science and back. Diabetes Metab 45: 419-428

Reinecke J (2018) Social movements and prefigurative organizing: confronting entrenched inequalities in occupy London. Organ Stud 39(9):1299-1321

Rohgalf J (2013) Democracy of the many? Occupy Wall Street and the dead end of prefiguration. Distinktion: Scand J Soc Theory 14(2):151-167

Roos J (2015) Towards a new anti-capitalist politics. ROAR Mag, 9 December

Sharma S (2014) Because the night belongs to lovers: occupying the time of precarity. Commun Crit/Cult Stud 11(1):5-14

Taviano S (2016) Translating resistance in art Aativism: Hip Hop and 100 Thousand Poets for Change. Transl Stud 9:282-297

Teleb A (2014) The Zeitgeist of Tahrir and pccupy, Truthout, 10 February. https:// truthout.org/articles/the-zeitgeist-of-tahir-and-occupy/

Trott CD (2016) Constructing alternatives: envisioning a critical psychology of prefigurative politics. J Soc Political Psychol 4(1):266-285

Yates L (2015) Rethinking prefiguration: alternatives, micropolitics and goals in social movements. Soc Mov Stud 14(1):1-21

Zahra-Mortada L (2015) OPANTISH: the Hashtag that became a movement. https://www.youtube.com/watch?v=B6LJhX-4LLg and https://monabaker. org/post/leil-zahra-mortada-opantish-the-hashtag-that-became-amovement-npa-034-2/

\section{Acknowledgements}

This article was written as part of the international research program on "The Body in Translation: Historicising and Reinventing Medical Humanities and Knowledge Translation" at the Centre for Advanced Study at the Norwegian Academy of Science and Letters in Oslo during the academic year 2019/2020. The screenshot from the Aya Tarek episode of Words of Women from the Egyptian Revolution (Fig. 1) is reproduced with permission from Leil Zahra-Mortada, founder of the Words of Women from the Egyptian Revolution project.

\section{Competing interests}

The author declares no competing interests.

\section{Additional information}

Supplementary information is available for this paper at https://doi.org/10.1057/s41599 020-0400-0

Correspondence and requests for materials should be addressed to M.B.

Reprints and permission information is available at http://www.nature.com/reprints

Publisher's note Springer Nature remains neutral with regard to jurisdictional claims in published maps and institutional affiliations.

\begin{abstract}
(c) (i) Open Access This article is licensed under a Creative Commons Attribution 4.0 International License, which permits use, sharing, adaptation, distribution and reproduction in any medium or format, as long as you give appropriate credit to the original author(s) and the source, provide a link to the Creative Commons license, and indicate if changes were made. The images or other third party material in this article are included in the article's Creative Commons license, unless indicated otherwise in a credit line to the material. If material is not included in the article's Creative Commons license and your intended use is not permitted by statutory regulation or exceeds the permitted use, you will need to obtain permission directly from the copyright holder. To view a copy of this license, visit http://creativecommons.org/ licenses/by/4.0/.
\end{abstract}

(c) The Author(s) 2020 